\title{
Analisa Operasi Ekonomis Pembangkit Termal untuk Melayani Beban Puncak Sistem Kelistrikan Sumbar
}

\author{
Syafii* dan Kartika Ika Putri \\ Jurusan Teknik Elektro, Fakultas Teknik, Universitas Andalas \\ *Corresponding author, e-mail: syafii@ft.unand.ac.id
}

\begin{abstract}
Abstrak - Operasi ekonomis sistem tenaga listrik merupakan aspek penting dalam manajemen sistem energi. Penelitian ini bertujuan melakukan analisa operasi ekonomis pembangkit termal dengan melakukan perhitungan untuk mendapatkan daya yang optimal serta biaya pembangkitan minimum, dengan menggunakan metode iterasi lamda. Studi kasus operasi pembangkit dalam melayani beban puncak diambil pada sistem kelistrikan Sumbar dengan asumsi unit pembangkit termal yang digunakan adalah PLTD, PLTG Pauh Limo, dan PLTU Ombilin. Besar daya beban (PD) yang akan dilayani oleh pembangkit termal tersebut diambil $15 \%$ dari kurva lama beban harian maksimum 512 MW yaitu 76,8 MW. Pembagian pembebanan untuk masing-masing unit pembangkit termal diperoleh melalui perhitungan economic dispatch. Hasil perhitungan operasi ekonomis untuk masing-masing pembangkit termal tersebut adalah $\mathrm{P}_{1}=1,25 \mathrm{MW}, \mathrm{P}_{2}=15,867 \mathrm{MW}$, dan $\mathrm{P}_{3}=59,683 \mathrm{MW}$ dengan total biaya pembangkitan Rp 57.295.977,57 per jam. Hasil perhitungan dan perbandingan dengan konfigurasi penjadwalan lainnya memperlihatkan bahwa dengan menggunakan perhitungan operasi ekonomis dalam penjadwalan pembangkit, telah diperoleh konfigurasi pembangkitan yang efisien dengan biaya operasi minimum untuk melayani beban puncak. Dengan demikian biaya pembangkitan dapat dihemat sekirannya kapasitas pembangkitan dapat dioptimalkan atau dioperasikan sesuai dengan hasil perhitungan operasi ekonomis.
\end{abstract}

\section{Kata Kunci : Pembangkit Termal, Penjadwalan Ekonomis, Metode Iterasi Lamda}

\begin{abstract}
The economical operation of electric power systems is an important aspect in energy system management. The research aim is analyzing the economical operation of thermal generators by performing calculations to obtain optimal power and minimum generation costs, using the lamda iteration method. The case study of the operation of the plant in serving the peak load is taken on the West Sumatera electrical system with the assumption that the thermal generator units used are the PLTD, PLTG Pauh Limo, and PLTU Ombilin power plant. The power demand (PD) to be serviced by the thermal generator is $76.8 \mathrm{MW}$ taken from $15 \%$ of maximum load duration curve $512 \mathrm{MW}$. The distribution of load demand for each thermal generating unit obtained through the economic dispatch calculation. The resulted of economical operation of the thermal generator $\mathrm{P}_{1}=1,25 \mathrm{MW}, \mathrm{P}_{2}=15,867$ $\mathrm{MW}$, and $\mathrm{P}_{3}=59,683 \mathrm{MW}$ with total generation cost 57,295,977.57 IDR/h. The calculation and comparison with other configuration scheduling results showed that by using economic dispatch method in power generation scheduling, has obtained efficient generation configuration with minimum operating cost to serve the peak load. Thus, the generation cost can be saved as the generation capacity can be optimized or operated in accordance with the calculation of economic operation.
\end{abstract}

Keywords : Thermal Power Plant, Economic Dispatch, Lamda Iteration Method

\section{Pendahuluan}

Seiring dengan kenaikan tariff listrik, pengurangan/penghapusan subsidi, diperlukan usaha-usaha konservasi dan diversifikasi energi listrik. Optimasi biaya pembangkitan untuk menurunkan biaya operasi pembangkit merupakan salah satu usaha konservasi energi disisi pembangkitan. Penyedia tenaga listrik bertujuan untuk memenuhi kebutuhan beban listrik secara efisien dengan biaya minimum. Untuk mencapai tujuan tersebut diperlukan penjadwalan unit pembangkit dengan biaya minimum, namun tetap dapat memenuhi kebutuhan daya beban dengan kualitas yang baik. Pengoperasian pembangkit secara ekonomis dipengaruhi oleh karakteristik pembangkit, limit daya output pembangkitan, biaya bahan bakar untuk mengoperasikan pembangkit, dan rugi-rugi saluran transmisi dan distribusi [1]. 
Sistem tenaga listrik yang sehat harus dapat memberikan keuntungan terhadap biaya yang diinvestasikan pada operasi pembangkitan. Konsumsi bahan bakar pembangkit menjadi suatu masalah yang perlu mendapat perhatian serius, mengingat komponen biaya penyediaan tenaga listrik terbesar adalah biaya bahan bakar yaitu sekitar $60 \%$ dari biaya total. Dari $60 \%$ biaya bahan bakar tersebut $85 \%$ diantaranya adalah biaya bahan bakar untuk pembangkit termal [2].

Pengaturan pembangkitan dilakukan agar proses pengiriman daya dapat berjalan dengan lancar. Pengaturan pembangkitan juga dilakukan untuk memperoleh biaya pembangkitan yang minimal yang dikenal dengan Economic Dispatch (ED) [3]. ED juga merupakan suatu proses untuk menentukan besar daya yang harus disuplai oleh setiap unit pembangkit dengan biaya total pembangkitan minimum. Untuk memenuhi beban tertentu dilakukan dengan cara membagi beban tersebut pada unit-unit pembangkit pada sistem secara optimal dan ekonomis dengan memperhatikan batasan-batasan operasional sistem dan pembangkit [4].

Sistem kelistrikan Sumbar sebagai salah satu bagaian dari sistem kelistrikan di Indonesia perlu melakukan studi operasi ekonomis dari waktu ke waktu mengingat adanya perubahan permintaan beban dan penambahan/perubahan misi operasi pembangkitan. Pasokan sistem kelistrikan Provinsi Sumatera Barat diluar kepulauan Mentawai berasal dari sistem interkoneksi $150 \mathrm{kV}$ Sumatera Bagian Tengah (Jambi-Sumbar-Riau) melalui 16 Gardu Induk dengan kapasitas total 744 MVA dan beban puncak sebesar 512 MW [5]. Pembangkit pada sistem Sumbar terdiri dari 3 sektor yaitu sektor Ombilin, sektor Teluk Sirih, sektor Bukittinggi. Dimana pada masing-masing sektor terdiri dari beberapa unit pembangkit yaitu sektor Ombilin terdiri dari 2 unit PLTU, 2 unit PLTG Pauh Limo. Sektor Teluk Sirih terdiri dari PLTU Teluk Sirih 2 unit. Sektor Bukittinggi terdiri dari PLTA Maninjau 4 unit, PLTA Batang Agam 3 unit, dan PLTA Singkarak 4 unit. Untuk memproduksi tenaga listrik yang optimal terhadap suatu permintaan beban oleh sejumlah unit pembangkit termal (PLTU, PLTG, PLTD), diperlukan suatu perhitungan operasi ekonomis.

Penelitian sebelumnya terkait operasi ekonomis pembangkit termal di Sumatera Barat dan Jambi telah dilakukan [6,7]. Operasi ekonomis Pembangkit Listrik Tenaga Sampah (PLTSa) dan PLTG Dalam Melayani Beban Puncak Kelistrikan
Sumbar telah dipaparkan dalam referensi [6]. Sedangkan operasi ekonomis dan unit commitment pembangkit termal pada sistem kelistrikan Jambi diberikan dalam referensi [7]. Pada artikel ini akan dipaparkan hasil analisa operasi ekonomis pembangkit termal untuk melayani beban puncak sistem kelistrikan Sumbar untuk skenario tiga unit pembangkit termal melayani beban puncak tahun 2016.

\section{Operasi Ekonomis Sistem Kelistrikan Sumbar}

Pembebanan sistem kelistrikan Sumbar disesuaikan dengan karakteristik dari unit pembangkitan. Secara umum, jenis prioritas pembangkit dalam sistem tenaga listrik dibagi menjadi tiga bagian yaitu:

a. Pembangkitan beban dasar (base load) mempunyai karakteristik biaya operasi murah. Pembangkitan jenis ini tidak dapat dihidupkan atau dimatikan dalam waktu yang singkat dan lambat dalam menaikan atau menurunkan daya terbangkitkan.

b. Pembangkit beban menegah (load follower): pembangkit tipe load follower merupakan pembangkit yang memiliki karakteristik lebih fleksibel namun juga lebih mahal biaya pengoperasiaannya apabila dibandingkan dengan pembangkit beban dasar.

c. Pembangkit beban puncak (Peaker): merupakan pembangkit yang memiliki karakteristik yang fleksibel sehingga responsif dalam hal kecepatan perubahan pembebanan dan pengaturan kondisi operasional dan non operasional dari pembangkit tersebut. Pembangkit untuk melayani beban puncak biasanya dipilih pembangkit termal dengan biaya operasi yang relatif mahal.

Studi operasi ekonomis sistem kelistrikan Sumbar diambil untuk pembebanan 512 MW seperti karekteristik kurva lama beban Gambar 1.

Berdasarkan misi pembangkit melayani permintaan beban dengan asumsi operasi beban puncak berdurasi 8 jam, beban menengah 16 jam dan beban dasar 24 jam diperoleh operasi beban dasar dan menengah 435,2 MW yang ditanggung oleh pembangkit PLTA, dan pembangkit PLTU Teluk Sirih serta pembangkit lainnya, sedangkan beban puncak 76,8 MW dijadwalkan untuk 
pembangkit termal. Operasi sistem kelistrikan Sumbar tersebut diperlihatkan pada Gambar 2

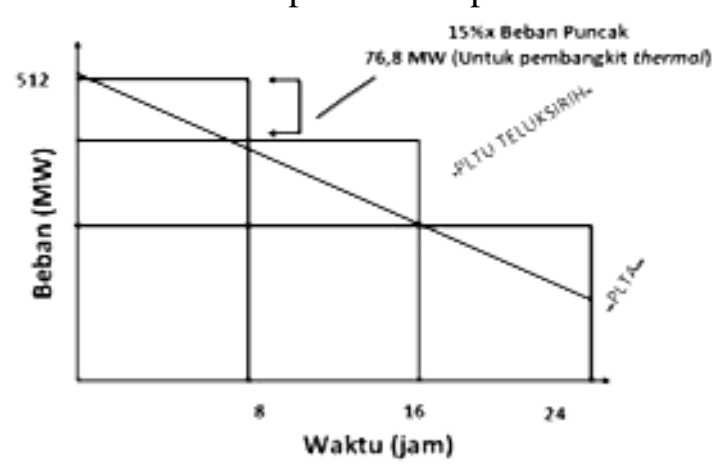

Gambar 1. Kurva lama beban sistem kelistrikan Sumbar

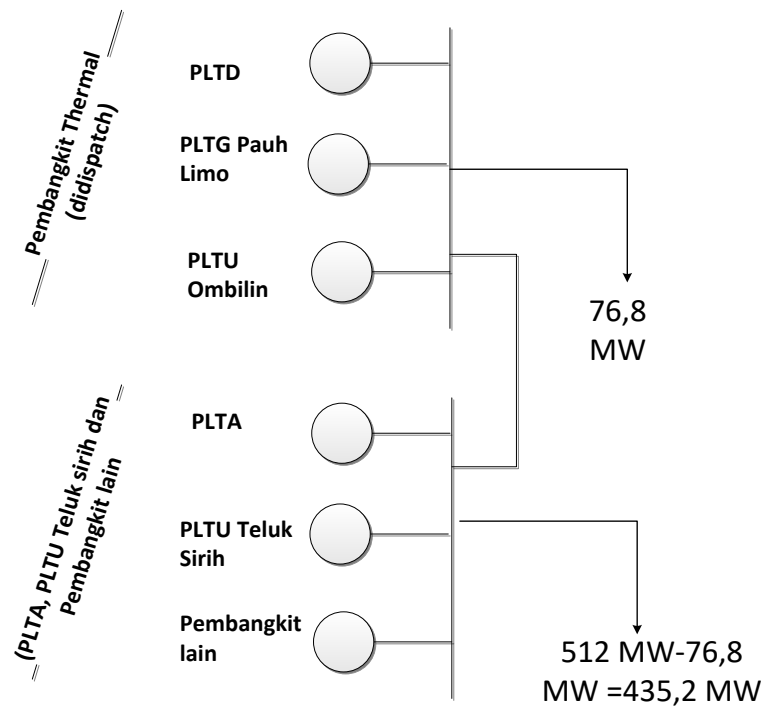

Gambar 2. Operasi sistem kelistrikan Sumbar

Pembangkit termal yang digunakan dalam memenuhi permintaan beban pucak diasumsikan sebagai berikut :

- $\quad$ PLTD 2 unit

- $\quad$ PLTG Pauh Limo 3 unit

- $\quad$ PLTU Ombilin 2 unit

Sistem kelistrikan dengan tiga jenis unit pembangkitan termal yang akan dijadwal untuk misi melayani beban puncak dengan batasan generator yang diberikan dan mengabaian rugirugi jaringan dapat dimodelkan seperti Gambar 3 berikut:

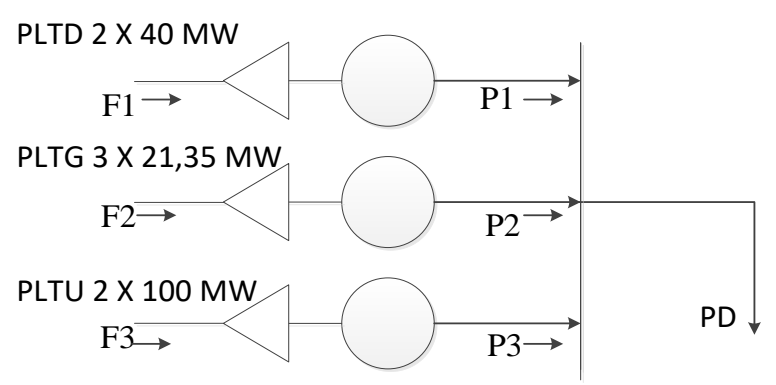

Gambar 3. Unit pembangkit termal

\section{Metode Iterasi Lamda}

Perhitungan operasi ekonomis untuk penjadwalan pembangkit dilakukan menggunakan metode iterasi lamda. Data yang dibutuhkan yaitu persamaan biaya bahan bakar (Rp/jam) dari masing-masing unit pembangkit termal, batasan daya pembangkit serta permintaan daya beban (PD). Metode iterasi lamda merupakan salah satu metode yang dapat digunakan untuk penjadwalan ekonomis [8]. Pada metode ini nilai awal lamda $(\lambda)$ diasumsikan terlebih dahulu, kemudian dengan menggunakan syarat optimum, dihitung daya output setiap pembangkit (Pi). Dengan mempertimbangkan kendala pembangkit diperiksa apakah jumlah total dari output sama dengan kebutuhan beban sistem, bila belum lamda $(\lambda)$ ditentukan kembali seperti alur gambar 4.

Proses dalam perhitungan penjadwalan ekonomis menggunakan metode iterasi lamda secara ringkas dilakukan dengan langkah perhitungan berikut: (i) mengansumsikan lamda ( $\lambda$ ); (ii) menghitung output daya masing-masing dari ketiga unit, diperoleh harga $\mathrm{P}_{1}, \mathrm{P}_{2}, \mathrm{P}_{3}$, untuk harga $\lambda$ yang pertama;(iii) bila harga $\mathrm{P}_{1}+\mathrm{P}_{2}+\mathrm{P}_{3}$ lebih kecil dari PD maka akan ditentukan kembali harga $\lambda$ yang lebih besar dari harga $\lambda$ yang pertama (dan sebaliknya), (iv) kemudian dihitung penyelesaiannya. Dengan diperoleh dua kali perhitungan maka secara ekstrapolasi dapat ditentukan harga $\lambda$ selanjutnya sampai dicapai harga yang dikehendaki $\mathrm{P}_{1}+\mathrm{P}_{2}+\mathrm{P}_{3} \cong \mathrm{PD}$. 


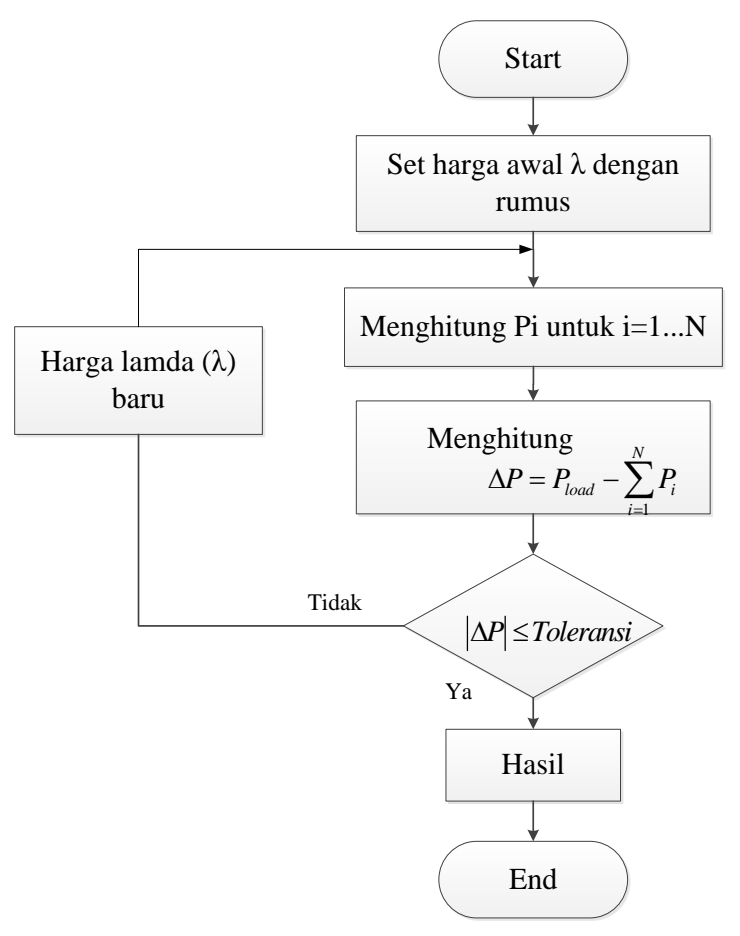

Gambar 4. Metode iterasi lamda

Ketika terjadi kondisi pembagian daya diluar dari batasan daya unit pembangkit, maka untuk proses iterasi berikutnya disetting daya pembangkitan berada pada batasan daya unit pembangkit tersebut, dan besaran daya total pembangkitan sama dengan kebutuhan beban dikurang daya pembangkit yang diset pada batas maksimum atau minimum $\left(\sum P i=P D-P_{(\text {mak } m \text { min })}\right)$.

Proses berikutnya adalah perhitungan biaya pembangkit menggunakan fungsi biaya yang telah ditentukan dengan persamaan:

$$
F_{i}\left(P_{i}\right)=\alpha_{i}+\beta_{i} P_{i}+\gamma_{i} P_{i}^{2}
$$

Persamaan untuk mendapatkan lamda awal menggunakan persamaan berikut:

$$
\lambda=\frac{P D+\sum \frac{\beta_{i}}{2 \gamma_{i}}}{\sum \frac{1}{2 \gamma_{i}}}
$$

Berdasarkan nilai lambda tersebut dapat diketahui nilai pembangkitan untuk setiap unit pembangkit.

$$
P_{i}^{(k)}=\frac{\lambda^{(k)}-\beta_{i}}{2 \gamma_{i}}
$$

Untuk beroperasi secara ekonomis, maka seluruh unit pembangkit harus beroperasi pada nilai increamental cost yang sama dan memenuhi batasan kendala pertidaksamaan. Jika daya unit pembangkit lebih kecil dari batasan minimum maka akan didapatkan solusi persamaan (5).

$$
\begin{aligned}
& P_{i} \leq P_{i} \min \\
& P_{i}=P_{i} \min
\end{aligned}
$$

Jika hasil perhitungan daya suatu unit pembangkit lebih besar dari batasan maksimum maka akan didapatkan solusi persamaan (7).

$$
\begin{aligned}
& P_{i} \geq P_{i} \max \\
& P_{i}=P_{i} \max
\end{aligned}
$$

Nilai total daya pembangkitan $\left(\sum P_{\mathrm{i}}\right)$ pada awal iterasi tidak selalu sesuai dengan total daya beban $(P D)$. Untuk menghitung besar perbedaan tersebut dihitung menggunakan persamaan berikut:

$$
\Delta P=P D-\sum P_{i}
$$

Jika nilai selisih $\Delta P$ belum dalam batas toleransi (konvergen) yang diizikan maka dilakukan proses perhitungan ulang untuk iterasi berikutnya. Proses perhitungan diteruskan sampai selisih daya mendekatai nol sesuai dengan kriteria penghentian yang di berikan.

\section{Deskripsi Data}

Data Sistem pembangkit termal menggunakan tipikal data Tabel 1 berikut:

Tabel 1. Fungsi biaya pembangkit termal

\begin{tabular}{|c|l|}
\hline Unit & \multicolumn{1}{|c|}{ Fungsi Biaya $(\mathrm{Rp} / \mathrm{jam})$} \\
\hline PLTD & $F_{1}=1.629 .281,434+870.815,99 P_{1}+95.610,448 P_{1}^{2}$ \\
PLTG & $F_{2}=304.563 .195,846593-34.564 .505,503306 P_{2}+1.109 .257,36579 P_{2}^{2}$ \\
PLTU & $F_{3}=0,534+0,321 P_{3}+5.343 P_{3}^{2}$ \\
\hline
\end{tabular}

Dengan batasan daya generator masing-masing unit termal untuk nilai daya minimum $\left(\mathrm{P}_{\min }\right)$ dan daya maksimum $\left(\mathrm{P}_{\text {mak }}\right)$, seperti pada Tabel 2.

Tabel 2. Batasan Daya Pembangkitan

\begin{tabular}{|l|c|c|}
\hline \multicolumn{1}{|c|}{ Unit Pembangkit } & $P_{\min }(\mathrm{MW})$ & $\begin{array}{c}\mathrm{P}_{\mathrm{mak}} \\
(\mathrm{MW})\end{array}$ \\
\hline PLTD & 1,25 & 32 \\
PLTG Pauh Limo & 6,45 & 17.08 \\
PLTU Ombilin & 28 & 80 \\
\hline
\end{tabular}




\section{Hasil dan Pembahasan}

Menggunakan perhitungan penjadwalan ekonomis metode iterasi lamda, harga awal lamda dihitung terlebih dahulu dengan persamaan (2), dengan nilai PD sebesar 78,8 MW sebagai nilai total beban yang sama dengan nilai jumlah daya yang akan dibangkitkan oleh unit termal (PLTU, PLTD dan PLTG). Proses dilanjutkan dengan mencari selisih daya $(\Delta \mathrm{P})$ sesuai dengan iterasi konvergensi, dimana proses iterasi akan diberhentikan apabila selisih antara total daya pembangkit dengan total daya permintaan beban mendekati nol. Hasil perhitungan penjadwalan ekonomis diperoleh nilai pembangkitan masingmasing unit termal adalah:

$$
\begin{aligned}
& \mathrm{P}_{1}=-1,089 \mathrm{MW} \\
& \mathrm{P}_{2}=15,87 \mathrm{MW} \text { dan } \\
& \mathrm{P}_{3}=62,01 \mathrm{MW}
\end{aligned}
$$

dengan total daya yang dibangkitkan tetap sama dengan total beban 78,8 MW, namun $P_{1}=-1,089$ MW berada dibawah batasan minimal. maka $P_{1}$ diset 1,25 MW sesuai batasan minimal dan diatur tetap konstan untuk iterasi berikutnya.. Dengan menghilangkan $\mathrm{P}_{1}$ dari unit termal yang dijadwalkan, nilai $\Delta \mathrm{P}$ menjadi: $-2,339$. Sehingga proses perhitungan dilanjutkan untuk iterasi ke-2 dihitung kembali keluran untuk daya $\mathrm{P}_{2}$ dan $\mathrm{P}_{3}$ dengan harga lamda yang baru yaitu sebesar: 637.767,57 Rp/MWh maka diperoleh:

$$
\begin{aligned}
& \mathrm{P}_{2}=15,867 \mathrm{MW} \text { dan } \\
& \mathrm{P}_{3}=59,683 \mathrm{MW}
\end{aligned}
$$

Selanjutnya dilakukan proses perhitungan total biaya pembangkitan dan diperoleh hasil sebesar Rp 57.295.977,57 per jam. Hasil perhitungan biaya operasi untuk masing-masing unit pembangkit termal diberikan pada Tabel 3. Dari hasil tersebut terlihat bawa pembangkit diesel dengan biaya operasi paling mahal akan mendapatkan jatah pembangkitan minimum atau pada batas bawahnya yaitu 1.25 MW. Sedangkan pembangkit pembangkit dengan biaya yang lebih murah akan di dispatch pada nilai yang lebih besar atau optimal.

Tabel 3. Hasil perhitungan biaya operasi (F)

\begin{tabular}{|l|c|c|}
\hline \multicolumn{1}{|c|}{$\begin{array}{c}\text { Unit } \\
\text { Pembangkit }\end{array}$} & $\begin{array}{c}\text { Kapasitas } \\
(\mathrm{MW})\end{array}$ & Biaya Operasi (Rp/h) \\
\hline PLTD & 1,25 & $2.867 .192,75$ \\
PLTG Pauh & 15,867 & $35.397 .010,87$ \\
$\begin{array}{l}\text { Limo } \\
\text { PLTU }\end{array}$ & 59,683 & $19.031 .773,57$ \\
$\begin{array}{l}\text { Ombilin } \\
\text { Total }\end{array}$ & 78,8 & $57.295 .977,57$ \\
\hline
\end{tabular}

Tabel 3 terlihat bahwa setelah dilakukan perhitungan penjadwalan ekonomis dengan iterasi lamda didapatkan total biaya tiga jenis unit pembangkit termal tersebut adalah sebesar $\mathrm{Rp}$ 57.295.977,57 per jam.

Hasil perhitungan operasi ekonomis pembangkit termal tersebut dibandingkan dengan nilai penjadwalan operasi pembangkitan lainnya

\begin{tabular}{|c|c|c|}
\hline Unit Pembangkit & $\begin{array}{c}\text { Kapasitas } \\
\text { (MW) }\end{array}$ & $\begin{array}{c}\text { Biaya Operasi } \\
\text { (Rp/jam) }\end{array}$ \\
\hline \multicolumn{3}{|c|}{ Konfigurasi -1 } \\
\hline $\begin{array}{l}\text { PLTD } \\
\text { PLTG Pauh Limo } \\
\text { PLTU Ombilin } \\
\text { Total }\end{array}$ & $\begin{array}{c}2 \\
18,275 \\
56,525 \\
76,8 \\
\end{array}$ & $\begin{array}{c}3.753 .355,21 \\
43.361 .779,8 \\
64.186 .425,25 \\
64.186 .425,25 \\
\end{array}$ \\
\hline \multicolumn{3}{|c|}{ Konfigurasi-2 } \\
\hline $\begin{array}{l}\text { PLTD } \\
\text { PLTG Pauh Limo } \\
\text { PLTU Ombilin } \\
\text { Total }\end{array}$ & $\begin{array}{c}2 \\
35 \\
37,8 \\
76,8 \\
\end{array}$ & $\begin{array}{c}3.753 .355,21 \\
48.279 .500,33 \\
16.636 .179,7 \\
68.669 .035,24 \\
\end{array}$ \\
\hline \multicolumn{3}{|c|}{ Konfigurasi-3 } \\
\hline $\begin{array}{l}\text { PLTD } \\
\text { PLTG Pauh Limo } \\
\text { PLTU Ombilin } \\
\text { Total }\end{array}$ & $\begin{array}{c}2 \\
20 \\
54,8 \\
76,8\end{array}$ & $\begin{array}{c}3.753 .355,21 \\
56.976 .032,10 \\
16.045 .243,9 \\
76.774 .631,21\end{array}$ \\
\hline
\end{tabular}
konfigurasi 1, 2 dan 3. Diperoleh hasil seperti terlihat pada Tabel 4.

Tabel 4. Biaya operasi tanpa penjadwalan ekonomis (penjadwalan perkiraan)

Dari hasil perhitungan Tabel 3 dan 4 diperoleh bahwa dengan menggunakan perhitungan penjadwalan ekonomis, telah diperoleh biaya operasi minimum untuk melayani beban puncak. Dengan demikian biaya pembangkitan dapat dihemat sekirannya kapasitas pembangkitan dapat dioptimalkan atau dioperasikan sesuai dengan hasil perhitungan penjadwalan ekonomis. Perbandingan biaya pembangkitan dan besar biaya penghematan yang diperoleh dapat dilihat pada Gambar 5.

Dari hasil tersebut terlihat bahwa penjadwalan ekonomis unit pembangkit termal, khususnya untuk pelayanan puncak sangat penting dalam rangka penghematan biaya pembangkitan sehingga dapat menekan biaya pokok penyediaan pembangkitan. Untuk mendapatkan hasil perhitungan yang akurat diperlukan input data khususnya fungsi biaya unit pembangkit termal yang valid sesuai dengan kondisi real dilapangan 
dengan mempertimbangkan biaya inverstasi, biaya bahan bakar biaya operasi dan pemeliharaan yang terbaru.

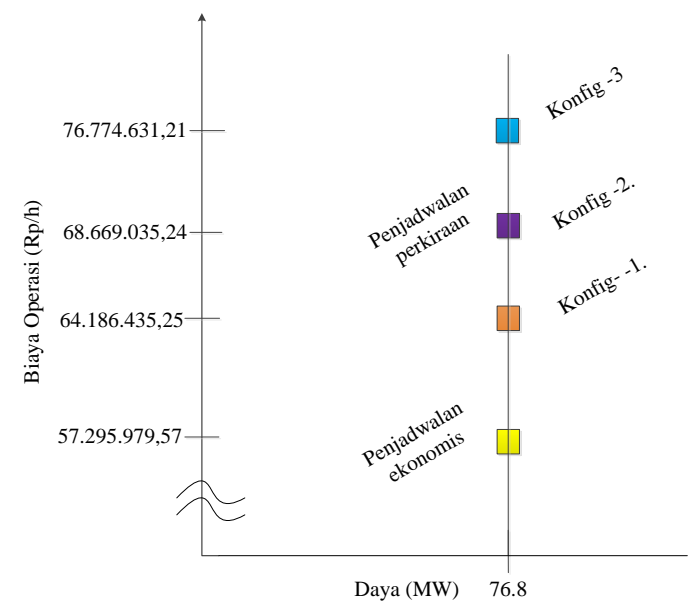

Gambar 5. Perbandingan biaya operasi

\section{Kesimpulan}

Hasil analisis dan perhitungan dengan menggunakan metode iterasi lamda diperoleh daya output masing-masing pembangkit $\mathrm{P}_{1}=1,25 \mathrm{MW}$, $\mathrm{P}_{2}=15,867 \mathrm{MW}$, dan $\mathrm{P}_{3}=59,683 \mathrm{MW}$. Total biaya pembangkitan minimum adalah $\mathrm{Rp}$ 57.295.977,57 per jam. Perbandingan dengan nilai penjadwalan pembangkitan lainnya mengasilkan biaya operasai yang lebih mahal dari yang diperoleh dengan perhitungan ED. Dari hasil perhitungan tersebut diperoleh bahwa dengan menggunakan perhitungan operasi ekonomis, telah diperoleh konfigurasi pembangkitan yang paling efisien dengan biaya operasi minimum untuk melayani beban yang sama. Dengan demikian biaya pembangkitan dapat dihemat sekirannya kapasitas pembangkitan dapat dioptimalkan atau dioperasikan sesuai dengan hasil perhitungan operasi ekonomis.

\section{Ucapan Terima Kasih}

Penulis mengucapkan terima kasih kepada Jurusan Teknik Elektro Fakultas Teknik Universitas Andalas atas bantuan pendanaan penelitian yang diberikan melalui kontrak penelitian No. 092/UN.16.09.D/PL/2017.

\section{Daftar Pustaka}

[1] Adrianti, "Penjadwalan Ekonomis Pembangkit Thermal dengan memperhitungkan Rugi-Rugi Saluran Transmisi Menggunakan Metode Algoritma Genetik," Jurnal Teknika, vol. 1, no. 33, pp. 41-47, 2010.

[2] Asmar, Yassir, and H. Tengku, "Pembuatan Aplikasi Untuk Analisis Economic Dispatch Stasiun Pembangkit Tenaga Listrik," Jurnal Electrichsan, vol. 1, no. 1, Mei 2014.

[3] B. T. Arozaq, R. S. Wibowo, and O. Penangsang, "Analisis Pembebanan Ekonomis pada Jaringan 500 kV Jawa Bali Menggunakan Software PowerWorld," Jurnal Teknik ITS, vol. 1, no. 1, pp. 1-6, Sep 2012.

[4] A. Violita, A. Priyadi, and I. Robandi, "Optimisasi Economic Dispatch pada Sistem Kelistrikan Jawa Bali $500 \mathrm{kV}$ menggunakan Differential Evolutionary Algorithm," Jurnal Teknik ITS, vol. 1, no. 1, pp. 115-118, Sep 2012.

[5] RUPTL (2016), Rencana Usaha Penyedia Tenaga Listrik PT PLN (Persero) Tahun 2016 s.d. 2025, Lampiran KepMen ESDM No. 5899 K/20/MEM/2016 Tanggal 10 Juni 2016.

[6] Monice and Syafii, "Operasi Ekonomis (Economic Dispatch) Pembangkit Listrik Tenaga Sampah (PLTSa) dan (PLTG) Dalam Melayani Beban Puncak Kelistrikan Sumbar," Jurnal Teknik Elektro, vol. 2, pp. 35-39, November 2013.

[7] Delima dan Syafii, "Operasi Ekonomis dan Unit Commitment Pembangkit Thermal pada Sistem Kelistrikan Jambi", Jurnal Nasional Teknik Elektro, Vol 5, No 3, November 2016

[8] A. J. Wood and B. F. Wollenberg, "Power Generation, Operation, and Control", 1st ed. Canada: John Willey \& Sons Inc, 1996.

\section{Biodata Penulis}

Syafii, menamatkan S1 di Jurusan Teknik Elektro Universitas Sumatera Utara (USU) tahun 1997. Pendidikan S2 bidang Energi Elektrik diselesaikan di Institute Teknologi Bandung (ITB) tahun 2002. Pendidikan S3 bidang Electrical Power System, diperoleh dari Universiti 
Teknologi Malaysia (UTM) Malaysia tahun 2011. Sejak tahun 1998 penulis terdaftar sebagai dosen di Jurusan Teknik Elektro, Fakultas Teknik, Universitas Andalas, Padang. Minat penelitiannya adalah: Komputasi Sistem Tenaga dan Pembangkit Energy Terbarukan.
Kartika Ika Putri, menamatkan S1 di Jurusan Teknik Elektro Universitas Andalas, Padang tahun 2017 dalam bidang Sistem Tenaga Listrik. Minat penelitiannya adalah: Optimalisasi Sistem Tenaga Listrik. 